\title{
Asynchronous coral spawning patterns on equatorial reefs in Kenya
}

\author{
Sangeeta Mangubhai* ${ }^{*}$ Peter L. Harrison \\ Coral Reef Research Centre, School of Environmental Science and Management, Southern Cross University, \\ Lismore, New South Wales 2480, Australia
}

\begin{abstract}
This study examined patterns of reef coral reproduction on lagoonal reefs adjacent to Mombasa in Kenya, at a latitude of $4^{\circ} \mathrm{S}$. A total of 401 colonies comprising 20 Acropora species was marked and repeatedly sampled between 2003 and 2005 to determine patterns of reproduction at the individual and population level. Spawning was inferred from the disappearance of mature oocytes and spermaries from sequential samples. In comparison to other regions, the overall pattern of coral reproduction in Kenya is one of asynchrony; Acropora species release gametes over a 7 mo period (October to April), with some level of 'temporal reproductive isolation' occurring between species in relation to the lunar month and lunar phase when the main spawning occurred. Extended gametogenic cycles were recorded in A. tenuis, A. valida and Acropora sp. 1, and quiescent non-reproductive periods between cycles were either very short or absent. Spawning occurred during both rising and maximum sea surface temperatures, during both neap and spring tides, and across all lunar periods. The findings from Kenyan reefs support the hypothesis of protracted breeding seasons and a breakdown of spawning synchrony nearer the equator. It is hypothesised that the high fecundities recorded in coral species in Kenya compared to other regions may allow individual reef coral populations to stagger their reproduction over 2 to 5 mo without incurring a significant reduction in fertilisation rates.
\end{abstract}

KEY WORDS: Sexual reproduction · Gametogenesis $\cdot$ Fecundity $\cdot$ Equatorial spawning $\cdot$ Indian Ocean

Resale or republication not permitted without written consent of the publisher

\section{INTRODUCTION}

Patterns of reproduction have been described for a wide range of marine organisms, including hard and soft corals, holothurians, starfish, sea urchins, brittle stars, molluscs, sponges and fish (e.g. Pearse 1969, Nzioka 1979, Lessios 1981, Pearse et al. 1988, Alino \& Coll 1989, Harrison \& Wallace 1990, Babcock \& Mundy 1992, Babcock et al. 1992, Srinivasan \& Jones 2006, Harrison \& Booth 2007, among others). The level of spawning synchrony can vary both between and within species, as was found among spawning invertebrates on the Great Barrier Reef (GBR) (Babcock et al. 1992).

'Mass coral spawning' was first used to describe the highly synchronous and multi-species coral spawning on the GBR (Harrison et al. 1984), where more than 40 species of scleractinian corals have been observed spawning together on 1 reef during 1 night, and more than 130 species have been recorded participating in mass spawning events during a few nights after full moon periods in October to December (Willis et al. 1985, Babcock et al. 1986). As coral spawning patterns were documented in other reef locations, it became clear that mass spawning events that occur on the GBR (Harrison et al. 1984, Babcock et al. 1986) and Western Australian reefs (Simpson 1991, Babcock et al. 1994) were unusual in relation to their magnitude and geographic scale (reviewed in Harrison \& Wallace 1990, Harrison \& Booth 2007). In other regions the term 'synchronous multispecific spawning' has been used to describe populations of 2 or more species of coral releas- 
ing gametes over the same night(s). Locations where large multispecific spawning occurs may see coral populations releasing gametes over 2 to 5 consecutive lunar months; examples include Japan, Singapore, Taiwan and Palau, among others (Dai et al. 1992, Hayashibara et al. 1993, Penland et al. 2004, Guest et al. 2005a).

These larger spawning events contrast markedly with corals in the northern Red Sea, where synchrony between different species is much less pronounced and spawning occurs in different seasons, months or during different lunar phases, despite a high degree of synchrony within individual species (Shlesinger \& Loya 1985, Shlesinger et al. 1998). Similarly, spawning patterns in coral species in Puerto Rico show strong seasonality and within-species synchrony, but reproduction occurs at different times over 3 mo for different species, rather than participating in a concentrated multispecific spawning event (Szmant 1986).

Very little detailed research has been done on the spawning patterns of corals in equatorial regions, compared to higher-latitude tropical reefs (reviewed by Harrison \& Wallace 1990, Harrison \& Booth 2007). It has been hypothesised that seasonality and synchrony of reproduction may break down towards the equator due to narrower variation in environmental parameters, such as temperature and tidal amplitudes, which are thought to influence the onset of reproduction and timing of spawning events (Oliver et al. 1988). It has also been hypothesised that under these more 'favourable', constant conditions, marine organisms on equatorial reefs may (1) have a more protracted reproductive season and (2) be capable of breeding yearround (Orton 1920, Pearse 1974). These hypotheses were initially supported by studies of coral reproduction over large latitudinal scales. Oliver et al. (1988) compared reproductive data from 5 sites extending from the southern GBR $\left(23.5^{\circ} \mathrm{S}\right)$ to the north coast of Papua New Guinea (PNG) $\left(5^{\circ} \mathrm{S}\right)$, and found a progressive breakdown in spawning synchrony north of the latitude $14^{\circ} \mathrm{S}$. In $\mathrm{PNG}, 2$ Acropora species had 2 gametogenic cycles per year, an extended reproductive season and spawning asynchrony both within and between species, whereas the same 2 species participated in a single synchronised mass-spawning event on the central and southern GBR (Oliver et al. 1988). Similarly, a latitudinal comparison showed that A. palifera released planulae throughout the year in northern PNG, while reproduction occurred once annually in spring on the southern GBR (Kojis 1986).

Some recent studies from the Pacific have challenged the equatorial asynchronous breeding hypothesis (Baird et al. 2002, Guest et al. 2005a,b). A 2 wk study in the Solomon Islands $\left(8^{\circ} \mathrm{S}\right)$ found some level of spawning synchrony among 28 Acropora species, with 12 species spawning 3 to $5 \mathrm{~d}$ after a full moon, despite the reefs being subject to small variations in sea temperature and tide (Baird et al. 2002). Corals from Singapore $\left(1^{\circ} \mathrm{N}\right)$ showed a high degree of synchrony with more than 18 species from 10 genera spawning over 3 nights in March (Guest et al. 2005b), and multispecific spawning and a protracted breeding season has been recorded in Palau $\left(7^{\circ} \mathrm{N}\right.$, Kenyon 1995, Penland et al. 2004). This led to the argument that no coastal environment is truly aseasonal and that, therefore, reproductive seasonality, multispecific spawning synchrony and mass spawning are also features of equatorial reefs (Guest et al. 2005b).

Kenya, located in the tropics between the latitudes $1^{\circ}$ and $5^{\circ} \mathrm{S}$, is ideally situated for determining the degree of spawning synchrony among reef corals at the equator. The main aims of this study were to (1) describe the pattern and timing of gametogenesis and spawning in 3 Acropora species, (2) determine the level of spawning synchrony within and among Acropora species, and (3) test the hypothesis that spawning synchrony breaks down in equatorial regions due to weak environmental cues governing the onset and timing of reproduction.

\section{MATERIALS AND METHODS}

Field work was done on lagoonal patch reefs in the Mombasa Marine National Reserve in Kenya $\left(4^{\circ} 3.7^{\prime} \mathrm{S}\right.$, $39^{\circ} 42.7^{\prime} \mathrm{E}$ ). A total of 401 colonies were marked and sampled for this study, comprising 53 'permanent' colonies that were repeatedly sampled to determine gametogenesis and breeding periods, and 348 'additional' colonies that were monitored for spawning. Ten permanent colonies of Acropora tenuis and 15 to 18 colonies of the A. nasuta group (sensu Wallace 1999) were repeatedly sampled at Nyali Reef from April to May 2003 and at Kijembe Reef from September 2004 to May 2005. Skeletal samples were collected for the $A$. nasuta group to assist with species identification and were found to be comprised of 18 Acropora sp. 1 and 15 A. valida. Acropora sp. 1 is currently a putative 'species' that was identified in Kenya and which has tentatively been placed in the $A$. nasuta group because it shares skeletal characteristics with A. valida, A. secale and A. lutkeni (Mangubhai 2007).

A single branch measuring 5 to $10 \mathrm{~cm}$ was removed from marked colonies during each collection period. In the first year, samples of Acropora tenuis, A. valida and Acropora sp. 1 were initially collected every 1 to $2 \mathrm{mo}$; collection was increased to 2 to $3 \mathrm{wk}$ intervals closer to the predicted period of spawning. In the second year, corals were initially sampled every 1 to $2 \mathrm{mo}$, but collection was increased to $2 \mathrm{wk}, 1 \mathrm{wk}$ and 1 to $4 \mathrm{~d}$ intervals closer to the predicted period of spawning. 
The colonies sampled ranged in size from 20 to $80 \mathrm{~cm}$, with smaller colonies sampled less frequently to avoid causing unnecessary stress to corals (Harrison \& Wallace 1990, Mangubhai 2007). The timing and frequency of collections in the second year were based on spawning periods recorded in the previous year, giving due consideration to the season and month, lunar phase and the size and maturity of oocytes observed in the field (Mangubhai \& Harrison 2006).

To determine the timing of spawning and the level of synchrony within and among Acropora species, colonies of a wide range of species were marked in September/October at Nyali Reef in 2003 (n = 117), and at Kijembe $(n=73)$ and at Mamba Reefs ( $n=73$ ) during the same period in 2004. Reproductive condition of oocytes was assessed in the field as follows: 'mature' if oocytes were strongly pigmented (Harrison et al. 1984), 'immature' if oocytes were smaller and pale or white, and 'empty' if oocytes were too small to view with the naked eye (Oliver et al. 1988, Mangubhai \& Harrison 2006). A single branch, measuring 5 to $10 \mathrm{~cm}$, was removed during each collection period. The frequency and timing of collections was based on the reproductive condition of oocytes observed in the field (after Harrison et al. 1984) and therefore the predicted time of spawning (Mangubhai \& Harrison 2006). Tissue samples were fixed in $10 \%$ formalin in seawater, decalcified in 0.5 to $5 \%$ hydrochloric acid and preserved in $70 \%$ ethanol. Under a stereomicroscope, 5 polyps were randomly selected from the centre portion of decalcified branches and the total number of oocytes was recorded, and the maximum length and perpendicular width of up to 6 randomly selected oocytes were measured on each mesentery. Unlike histological sectioning, this method enables all oocytes in a polyp to be counted, rather than a sub-sample; hence, it is a more accurate measure of fecundity (Wallace 1985). In 66 corymbose colonies of 11 Acropora species, the length of the sterile zone at the branch tip was measured under a stereomicroscope. Branches of 9 Acropora species were collected and maintained in separate aquaria for 3 to $4 \mathrm{~d}$ from December 2004 to March 2005, after full moon periods, to obtain data on the timing of spawning.

Sea surface temperature (SST) readings were taken every hour by temperature loggers (HOBO StowAway TidbiT) deployed at Coral Gardens from May 2003 to June 2004 and at Nyali Reef from April 2003 to December 2005 (0.5 m low water spring tide), and mean weekly averages were calculated. Solar radiation and rainfall data from 1997 to 2003 were obtained from the Kenya Meteorological Department. Photoperiod data were calculated from sunrise and sunset times listed for Nairobi, Kenya (www.timeanddate.com/worldclock/ astronomy/html).

\section{RESULTS}

\section{Gametogenesis}

Acropora tenuis and almost all colonies of $A$. valida and Acropora sp. 1 had a single annual cycle of gametogenesis, with the onset of oogenesis preceding spermatogenesis by 4 to 6 mo (Fig. 1). In A. tenuis, oogenesis occurred for 8 to $11 \mathrm{mo}$, from May to March, and spermatogenesis occurred for 3 to $4 \mathrm{mo}$, from late
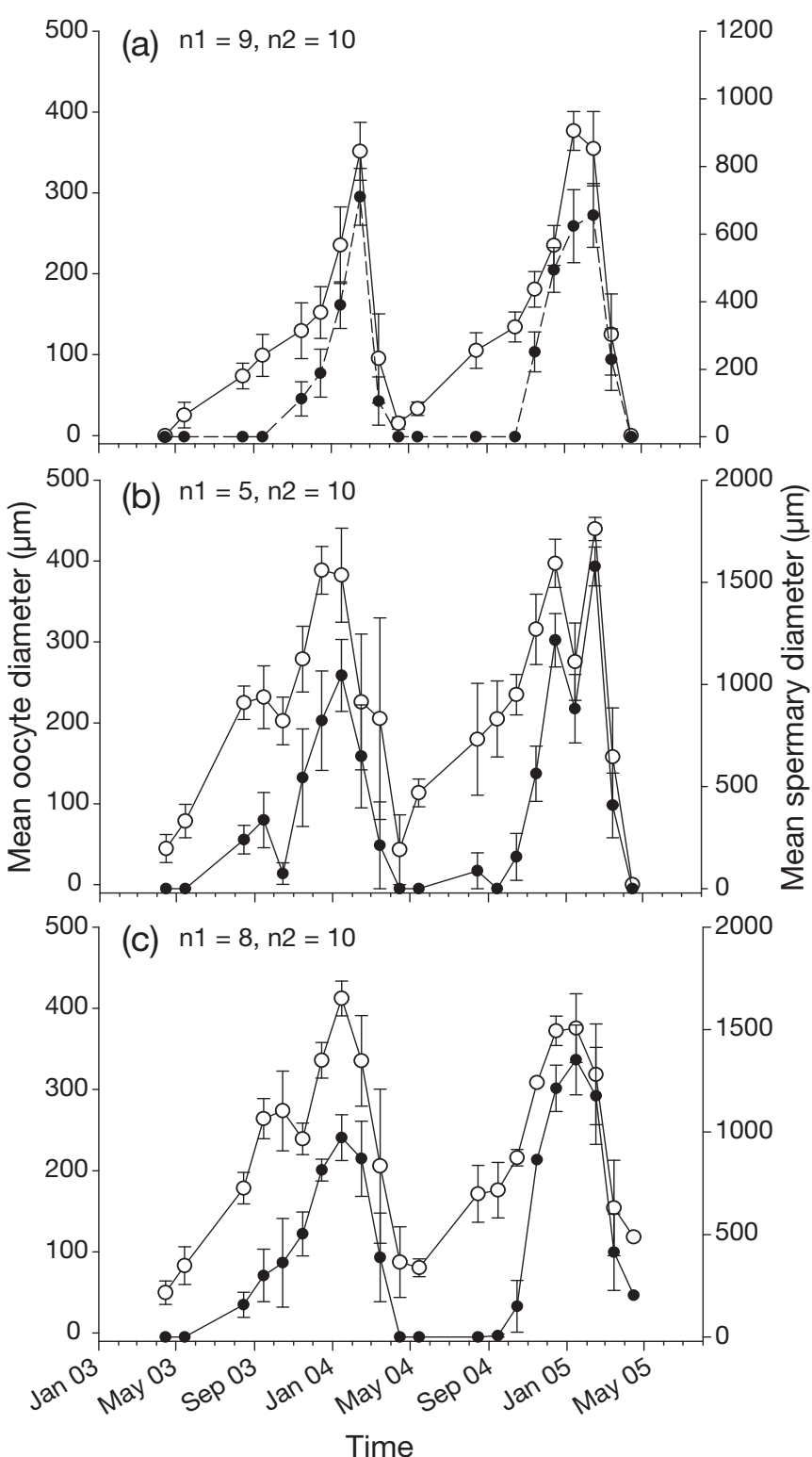

Fig. 1. (a) Acropora tenuis, (b) A. valida and (c) Acropora sp. 1. Seasonal changes in mean oocyte $(O$, left $y$-axis) and spermary (, right $y$-axis) diameter of permanently marked colonies. Gamete sizes were averaged for each month. n1, n2: $=$ number of colonies sampled in the first and second year, respectively. Error bars are SE 
November to March (Fig. 1a). A closer examination of the gametogenic cycles in individual colonies revealed that while the onset of gametogenesis varied between individual colonies by a few weeks, the population of A. tenuis became more synchronous as gametogenesis progressed with rapid maturation in the 1 to 2 mo prior to spawning.

In Acropora valida and Acropora sp. 1, oogenesis occurred for 11 to $12 \mathrm{mo}$, from April to March, and spermatogenesis occurred for 7 to $8 \mathrm{mo}$, from August to March (Fig. 1b,c). A closer examination of the gametogenic cycles in individual colonies revealed that both oocyte and spermary maturation were less synchronous in A. valida and Acropora sp. 1 populations, than in $A$. tenuis. Biannual cycles of gametogenesis were recorded in 1 colony of $A$. valida and 1 colony of Acropora sp. 1, which represent $3.8 \%$ of the permanently marked colonies studied. The presence of small-sized (50 to $100 \mu \mathrm{m}$ ) as well as larger, mature oocytes in biannually reproducing colonies resulted in a slight decrease in the mean oocyte and spermary diameter shown in Fig. 1b,c. Quiescent non-reproductive periods between gametogenic cycles were absent within individual colonies or occurred for a short period of 1 to 2 mo. However, at the population level (i.e. when individual colonies are averaged for the sampled population), there was no obvious quiescent period between gametogenic cycles for the 3 species (Fig. 1).

\section{Fecundity}

Fecundity in Acropora species is usually expressed as the total number of oocytes polyp ${ }^{-1}$ (Wallace 1985, 1999). Of the 401 Acropora colonies sampled over the 2 yr study period, $303(75.6 \%)$ were observed with mature gametes and $33(8.2 \%)$ did not produce gametes. The remaining corals died from crown-ofthorns starfish predation or mechanical damage from local fishers. Mature pigmented oocytes were observed in the field and in fresh samples examined under a stereomicroscope on average 2 to $3 \mathrm{wk}$ prior to spawning, though in some colonies of Acropora sp. 1 and A. valida, mature oocytes were observed for 4 to $6 \mathrm{wk}$. Mature white or pale/cream oocytes were recorded in $12(63.2 \%)$ species, and in $55(13.7 \%)$ of the 401 colonies studied. Mean oocyte diameter ranged from 404.4 to $557.5 \mu \mathrm{m}$ and mean spermary diameter from 445.0 to $1507.2 \mu \mathrm{m}$ among 19 Acropora species studied (Table 1). Regression analyses were done to determine relationships between gamete size and numbers. There was no significant relationship between mean oocyte diameter and fecundity $\left(F_{1,17}=3.36, \mathrm{p}=0.085, \mathrm{r}^{2}=0.16\right)$ or between mean oocyte and mean spermary diameter $\left(F_{1,17}=1.87, \mathrm{p}=0.189, \mathrm{r}^{2}=0.10\right)$ among these Acropora species. However, there was a significant positive relationship between fecundity and mean spermary diameter $\left(F_{1,17}=25.4, \mathrm{p}<0.001, \mathrm{r}^{2}=0.60\right)$. Gametes were absent in axial corallites, and the length of the sterile zone

Table 1. Acropora spp. Mean number of oocytes, and mean diameter of oocytes and spermaries in reproductively mature species (ordered in decreasing mean oocyte size). n1: number of colonies sampled between April 2003 to May 2004 ; n2 = number of colonies sampled between September 2004 to May 2005. Egg colours: $w=$ white, $o=$ orange, $p=$ pink, $c=$ cerise

\begin{tabular}{|c|c|c|c|c|c|c|c|c|c|c|}
\hline \multirow[t]{2}{*}{ Species } & \multirow[t]{2}{*}{$\mathrm{n} 1$} & \multirow[t]{2}{*}{$\mathrm{n} 2$} & \multicolumn{2}{|c|}{ No. of oocytes } & \multicolumn{3}{|c|}{ Oocyte size $(\mu \mathrm{m})$} & \multicolumn{2}{|c|}{ Spermary size $(\mu \mathrm{m})$} & \multirow{2}{*}{$\begin{array}{l}\text { Egg } \\
\text { colour }\end{array}$} \\
\hline & & & Mean & $\mathrm{SD}$ & Mean & Max. & $\mathrm{SD}$ & Mean & SD & \\
\hline A. cytherea & 3 & 3 & 6.9 & 1.6 & 557.5 & 667.0 & 56.7 & 445.0 & 126.9 & $\mathrm{w}$ \\
\hline A. nasuta & 4 & 6 & 11.0 & 3.8 & 523.1 & 933.3 & 148.2 & 881.5 & 353.9 & $\mathrm{o}, \mathrm{w}$ \\
\hline A. mossambica & 12 & 23 & 19.3 & 5.7 & 522.8 & 800.4 & 68.3 & 1354.8 & 443.0 & $\mathrm{o}, \mathrm{p}, \mathrm{w}$ \\
\hline A. subulata & 5 & 12 & 9.8 & 2.1 & 509.7 & 750.0 & 68.4 & 743.9 & 247.3 & $\mathrm{o}, \mathrm{p}, \mathrm{c}, \mathrm{w}$ \\
\hline A. gemmifera & 3 & 5 & 14.3 & 7.6 & 506.7 & 850.0 & 120.0 & 844.4 & 373.7 & $\mathrm{p}$ \\
\hline A. secale & 9 & 9 & 15.1 & 5.1 & 498.9 & 733.7 & 95.3 & 1312.1 & 586.9 & $\mathrm{o}, \mathrm{p}, \mathrm{w}$ \\
\hline A. nana & 0 & 3 & 10.6 & 1.6 & 493.1 & 655.9 & 57.7 & 816.6 & 249.2 & $\mathrm{p}$ \\
\hline A. lutkeni & 1 & 2 & 19.2 & 2.2 & 491.7 & 606.7 & 58.9 & 1507.2 & 579.0 & $o, p$ \\
\hline Acropora sp. 1 & 30 & 17 & 17.8 & 5.8 & 479.5 & 833.3 & 76.1 & 1467.5 & 621.8 & $\mathrm{o}, \mathrm{p}, \mathrm{w}$ \\
\hline A. digitifera & 3 & 3 & 8.7 & 3.1 & 474.6 & 716.7 & 84.1 & 584.1 & 253.0 & o \\
\hline A. kosurini & 2 & 1 & 8.3 & 2.4 & 471.7 & 600.0 & 72.0 & 676.3 & 338.4 & $\mathrm{o}, \mathrm{p}$ \\
\hline A. valida & 24 & 25 & 16.7 & 5.6 & 468.3 & 733.3 & 87.4 & 1352.1 & 582.5 & $\mathrm{o}, \mathrm{p}, \mathrm{w}$ \\
\hline A. humilis & 9 & 17 & 19.7 & 6.6 & 451.0 & 650.3 & 70.1 & 1202.1 & 538.7 & $\mathrm{o}, \mathrm{p}, \mathrm{w}$ \\
\hline A. tenuis & 22 & 20 & 17.9 & 5.1 & 448.3 & 766.7 & 81.2 & 910.6 & 382.7 & $\mathrm{p}, \mathrm{c}$ \\
\hline A. samoensis & 8 & 6 & 16.0 & 6.0 & 434.4 & 667.0 & 95.6 & 1023.0 & 433.8 & $\mathrm{o}, \mathrm{p}, \mathrm{w}$ \\
\hline A. sordiensis & 19 & 20 & 21.5 & 6.2 & 427.8 & 700.0 & 70.0 & 1368.1 & 500.8 & $\mathrm{o}, \mathrm{p}, \mathrm{w}$ \\
\hline A. glauca & 1 & 0 & 14.4 & 0.9 & 417.1 & 516.7 & 36.5 & 933.3 & 326.4 & $\mathrm{p}$ \\
\hline A. divaricata & 29 & 33 & 18.9 & 7.3 & 407.4 & 700.0 & 80.7 & 1013.7 & 396.1 & $\mathrm{o}, \mathrm{p}, \mathrm{w}$ \\
\hline A. branchi & 6 & 0 & 12.0 & 8.2 & 404.4 & 516.7 & 89.7 & 1400.0 & 587.5 & $\mathrm{o}, \mathrm{w}$ \\
\hline Total & 190 & 205 & & & & & & & & \\
\hline
\end{tabular}


at the branch tip ranged from 0.3 to $2.2 \mathrm{~cm}$ and averaged $1.0 \mathrm{~cm}( \pm 0.4 \mathrm{SD})$ in the 66 colonies of the 11 Acropora species sampled. Sub-fecund radial corallites extended approximately 1 to $3 \mathrm{~cm}$ below the axial corallite (S. Mangubhai pers. obs.).

\section{Spawning patterns}

Spawning periods for Acropora species sampled from 2004 to 2005 were inferred from the disappearance of gametes from sequential tissue samples (Fig. 2). Spawning data from the previous year were published in Mangubhai \& Harrison (2006). Table 2 shows the proportion of colonies sampled (\%) that spawned in each lunar month during the 2 study years. Spawning in Acropora species was asynchronous, and extended over $7 \mathrm{mo}$, from October to April in both study years, with the majority of colonies (77 to $78 \%$ ) releasing gametes between January and March (Fig. 2, Table 2). In 2004, the main spawning month was March, with $35 \%$ of colonies releasing gametes, while in 2005 the main spawning month was February, with $42 \%$ of colonies releasing gametes. The greatest overlap in species spawning occurred in February, with 12 and 11 species releasing gametes in 2004 and 2005, respectively (Table 2 ).

The main (or peak) spawning months for individual species were found to differ between species (Table 2). In the majority of species, spawning was split over 2 to 5 mo. The main spawning months were January, February or March, with 30 to $80 \%$ (mean = $52.7 \%$ ) of the population of each species releasing gametes during these months. No species had their main spawning period in the inter-monsoonal month of April, prior to the onset of the southeast monsoon season. In some species, the timing of spawning varied between consecutive years, while in others, the timing was more consistent. For example, Acropora sordiensis spawned over 2 mo, from December to January, in the first year, but over $4 \mathrm{mo}$, from December to March, in the second year. A. valida and Acropora sp. 1 spawned over 3 to $4 \mathrm{mo}$, from December to March, with the main spawning period for the 2 species occurring in different months in 2004 (February and March, respectively), and in the same month in 2005 (February). In some species (for example, A. gemmifera and $A$. digitifera), spawning occurred in October/November in both study years, and did not overlap with most of the other species. A. subulata and $A$. nasuta spawned both early in the reproductive season in October/November, as well as towards the end of the season in February/ March in 2004 to 2005, with a 3 mo period in between when no colonies released gametes (Fig. 2, Table 2).

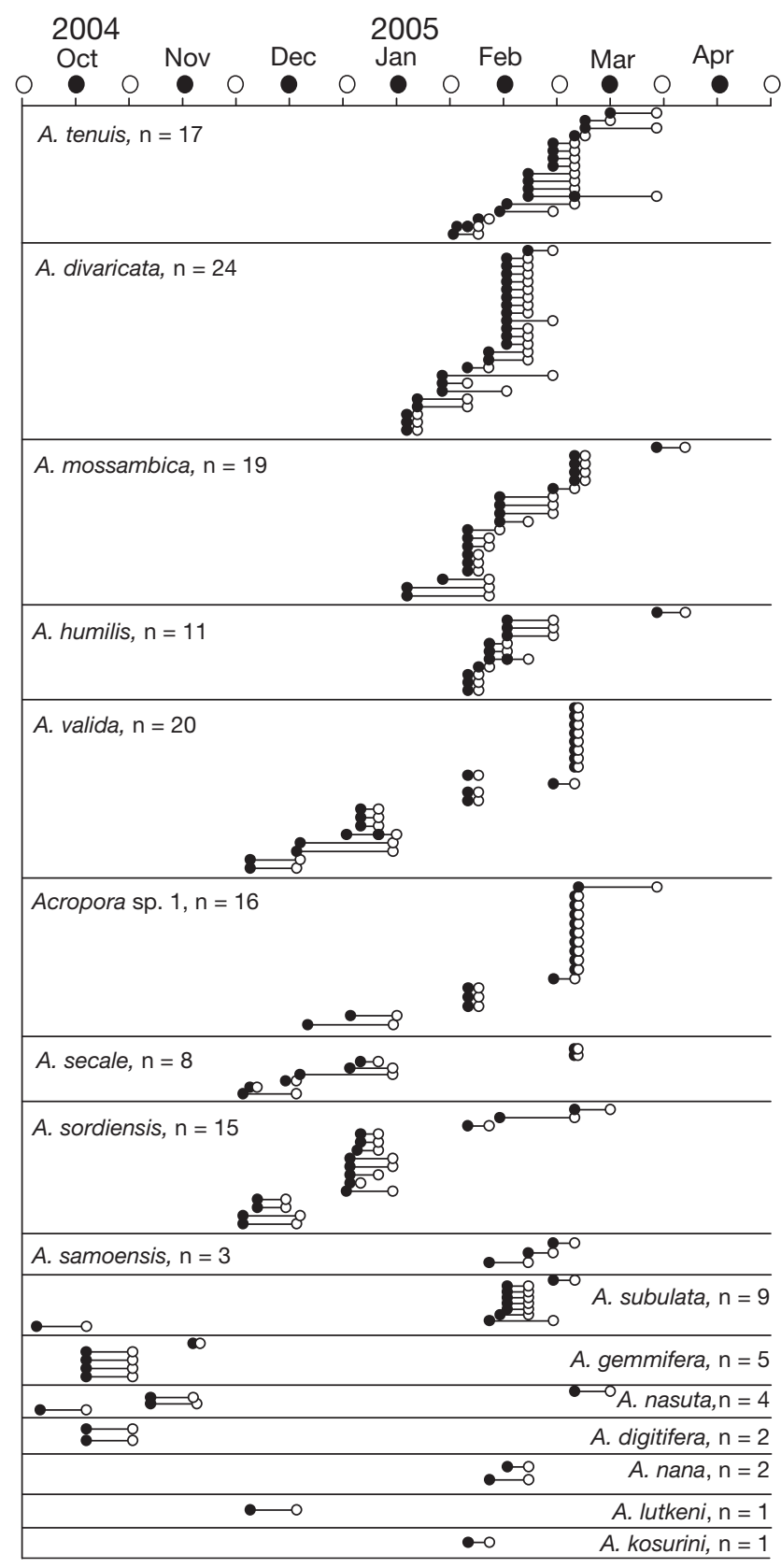

Fig. 2. Acropora spp. Reproductive periods for marked colonies at Kijembe and Mamba Reefs from 2004 to 2005. Each line represents a spawning record for a single colony. $(\bullet-0)$ Period between last sample date when gametes were present $(\bullet)$ and subsequent sample date when gametes were absent (O); (- — ) closed circles in the middle represent date when some gametes had disappeared, indicating partial spawning occurred. O: full moon, $\mathbf{0}$ : new moon

Spawning in Acropora species in Kenya occurred over a range of lunar phases, with 9 species spawning in the third lunar quarter (after full moon), 7 in the fourth quarter, 5 in the first quarter (after new moon), and 2 species in the second quarter (Table 3). Most 
Table 2. Acropora spp. Proportion of colonies sampled (\%) that spawned in each lunar month from April 2003 to May 2004 at Nyali Reef, and from September 2004 to May 2005 at Kijembe and Mamba Reefs. Only months where spawning was recorded are shown. Abs: colonies where no mature or maturing gametes were observed. Dead colonies and those that did not spawn have been excluded. Peak spawning month for individual species highlighted in grey

\begin{tabular}{|c|c|c|c|c|c|c|c|c|c|c|c|c|c|c|c|c|c|c|}
\hline \multirow{2}{*}{ Species } & \multirow{2}{*}{$\mathrm{n}$} & \multirow{2}{*}{$\overline{\text { Oct }}$} & \multirow{2}{*}{$\begin{array}{l}2003 \\
\text { Nov }\end{array}$} & \multirow{2}{*}{$\overline{\mathrm{Dec}}$} & \multirow{2}{*}{ Jan } & \multirow{2}{*}{$\begin{array}{c}\overline{2} \\
\text { Feb }\end{array}$} & \multirow{2}{*}{$\begin{array}{l}04- \\
\text { Mar }\end{array}$} & \multirow{2}{*}{$\overline{\text { Apr }}$} & \multirow[t]{2}{*}{ Abs } & \multirow[t]{2}{*}{$\mathrm{n}$} & \multicolumn{3}{|c|}{$-2004-$} & \multicolumn{4}{|c|}{$-2005-$} & \multirow[t]{2}{*}{ Abs } \\
\hline & & & & & & & & & & & Oct & Nov & Dec & Jan & Feb & Mar & Apr & \\
\hline A. gemmifera & 1 & 100 & & & & & & & & 5 & 80 & 20 & & & & & & \\
\hline A. cytherea & 2 & & 50 & & & & & & 50 & 1 & & & & & & & & 100 \\
\hline A. digitifera & 2 & & 100 & & & & & & & 3 & 67 & & & & & & & 33 \\
\hline A. nasuta & 4 & 25 & & & & 25 & 50 & & & 5 & 20 & 40 & & & & 20 & & 20 \\
\hline A. sordiensis & 17 & & & 18 & 71 & & & & 12 & 16 & & & 31 & 44 & 13 & 6 & & 6 \\
\hline Acropora sp. 1 & 29 & & & 3 & 14 & 24 & 55 & & 3 & 16 & & & & 13 & 25 & 63 & & \\
\hline A. secale & 6 & & & 17 & 17 & 17 & 33 & & 17 & 8 & & & 38 & 38 & & 25 & & \\
\hline A. valida & 23 & & & 13 & 22 & 30 & 17 & 9 & 9 & 21 & & & 10 & 29 & 14 & 43 & & 5 \\
\hline A. lutkeni & 1 & & & & 100 & & & & & 1 & & & 100 & & & & & \\
\hline A. kosurini & 1 & & & & 100 & & & & & 1 & & & & & 100 & & & \\
\hline A. humilis & 10 & & & & 30 & 30 & 40 & & & 14 & & & & & 71 & & 7 & 21 \\
\hline A. divaricata & 21 & & & & 19 & 19 & 48 & 10 & 5 & 26 & & & & 23 & 69 & & & 8 \\
\hline A. mossambica & 11 & & & & 18 & 27 & 45 & 9 & & 21 & & & & 14 & 52 & 19 & 5 & 10 \\
\hline A. tenuis & 19 & & & & & 21 & 58 & 5 & 16 & 19 & & & & 11 & 58 & 21 & & 11 \\
\hline A. branchi & 4 & & & & & 25 & & & 75 & 0 & & & & & & & & \\
\hline A. glauca & 1 & & & & & 100 & & & & 0 & & & & & & & & \\
\hline A. samoensis & 6 & & & & & 50 & 33 & & 17 & 5 & & & & & 60 & & & 40 \\
\hline A. subulata & 3 & & & & & 67 & 33 & & & 10 & 10 & & & & 80 & & & 10 \\
\hline A. microphthalma & 1 & & & & & & & & 100 & 0 & & & & & & & & \\
\hline A. nana & 0 & & & & & & & & & 2 & & & & & 100 & & & \\
\hline Overall proportion & - & 1 & 2 & 5 & 20 & 23 & 35 & 4 & 10 & - & 5 & 2 & 6 & 17 & 42 & 18 & 1 & 10 \\
\hline Total (no. of species) & 19 & 2 & 2 & 4 & 9 & 12 & 10 & 4 & 10 & 17 & 4 & 2 & 4 & 7 & 11 & 7 & 2 & 11 \\
\hline
\end{tabular}

species spawned in more than 1 lunar phase. For example, A. mossambica spawned predominantly in the fourth lunar quarter, between Lunar Days 21 and 24 , but 1 colony spawned in the first quarter, and 2 colonies in the third quarter (Table 3). The 5 species belonging to the $A$. nasuta group spawned in the third and fourth lunar quarters, with some colonies of $A$. valida, A. secale and Acropora sp. 1 spawning on the same night, 2 March 2005, the sixth night after full moon. Three branches kept in aquaria (2 Acropora sp. 1 and 1 A. valida) spawned on 2 March 2005 between 20:55 and 21:19 h, and spawning was confirmed in field colonies sampled the next day.

\section{Environmental parameters}

The annual range in mean weekly SSTs at Coral Gardens and Nyali Reef were similar and showed a marked seasonal pattern with mean weekly temperatures ranging from 24.7 to $29.7^{\circ} \mathrm{C}$, a difference of $5^{\circ} \mathrm{C}$ (Fig. 3a). Acropora species spawned over the northeast monsoon season and the inter-monsoonal months, from October to April, with spawning peaking between January and March, when SSTs were at their annual summer maximum, averaging $28.3^{\circ} \mathrm{C}$. Spawning occurred over the temperature range 26 to $29^{\circ} \mathrm{C}$, just prior to and throughout the short rains in Novem- ber, but finished prior to peak rainfall in May on the Kenya coast (Fig. 3b) and when solar radiation was generally highest, above $20 \mathrm{MJ} \mathrm{m}^{-2}$ (Fig. 3d). In Kenya, spring tides occur 1 or $2 \mathrm{~d}$ after the full and new moons, and neap tides just after the second and last lunar quarter. Spawning in Acropora species occurred over a range of lunar phases, and hence over both spring and neap tides. The timing of sunrise and sunset varies annually by $30 \mathrm{~min}$ in Kenya and there is little seasonal variation in day length, with the greatest range being 10 min (Fig. 3c). Spawning in Acropora species occurred when day length was 12:05 to 12:12 h, with peak spawning occurring just after the longest day length in the year.

\section{DISCUSSION}

\section{Seasonality and patterns of coral reproduction}

Compared to higher-latitude tropical and subtropical reefs, very little detailed research has been done on spawning patterns of scleractinian corals in equatorial regions (Harrison \& Wallace 1990), where it has been hypothesised that seasonality and synchrony of reproduction may break down due to a narrow range in variation in environmental parameters that are thought to influence the onset and timing of reproduc- 
Table 3. Acropora spp. Spawning periods inferred for colonies from samples taken between 1 and $7 \mathrm{~d}$ apart. Lunar days are divided into 4 lunar quarters: 1 st $=$ Days $0-7,2$ nd $=$ Days $8-14 ; 3$ rd $=$ Days 15-21, 4th = Days 22-29, where Lunar Day 0 = new moon and Lunar Day $15=$ full moon. Full moons were on 27 December in 2004, and 25 January, 24 February, 26 March in 2005

\begin{tabular}{|c|c|c|c|c|}
\hline $\begin{array}{l}\text { Lunar period } \\
\text { and species }\end{array}$ & $\mathrm{n}$ & Mature & Absent & $\begin{array}{c}\text { Sampling } \\
\text { interval (d) }\end{array}$ \\
\hline \multicolumn{5}{|l|}{ 1st quarter } \\
\hline \multirow[t]{2}{*}{ A. divaricata } & 3 & 14 Jan ‘05 & 17 Jan ‘05 & 3 \\
\hline & 11 & $11 \mathrm{Feb} ` 05$ & 17 Feb ‘05 & 6 \\
\hline A. gemmifera & 1 & 15 Nov ‘04 & 17 Nov '04 & 2 \\
\hline A. mossambica & 1 & 9 Feb ‘05 & 16 Feb ‘05 & 7 \\
\hline A. nana & 1 & $11 \mathrm{Feb} ` 05$ & 17 Feb ‘05 & 6 \\
\hline A. subulata & 4 & 11 Feb ‘05 & 17 Feb ‘05 & 6 \\
\hline \multicolumn{5}{|l|}{ 2nd quarter } \\
\hline A. divaricata & 1 & 17 Feb ‘05 & 24 Feb ‘05 & 7 \\
\hline A. samoensis & 1 & 17 Feb ‘05 & 24 Feb 05 & 7 \\
\hline \multicolumn{5}{|l|}{ 3rd quarter } \\
\hline A. divaricata & 1 & 24 Jan ‘05 & 31 Jan ‘05 & 7 \\
\hline \multirow{2}{*}{ A. mossambica } & 1 & 24 Feb ‘05 & 2 Mar ‘05 & 6 \\
\hline & 1 & 26 Mar ‘05 & 2 Apr `05 & 7 \\
\hline A. samoensis & 1 & 24 Feb ‘05 & 2 Mar ‘05 & 6 \\
\hline \multirow[t]{2}{*}{ A. secale } & 1 & 1 Dec ‘04 & 3 Dec ‘04 & 2 \\
\hline & 2 & 2 Mar ‘05 & 3 Mar ‘05 & 1 \\
\hline A. sordiensis & 1 & 29 Dec ‘04 & 1 Jan ‘05 & 3 \\
\hline A. subulata & 1 & 24 Feb ‘05 & 2 Mar ‘05 & 6 \\
\hline \multirow[t]{2}{*}{ A. tenuis } & 1 & 28 Jan ‘05 & 31 Jan ‘05 & 3 \\
\hline & 4 & 24 Feb ‘05 & 2 Mar `05 & 6 \\
\hline \multirow[t]{2}{*}{ A. valida } & 1 & 24 Feb ‘05 & 2 Mar ‘05 & 6 \\
\hline & 8 & 2 Mar ‘05 & 3 Mar ‘05 & 1 \\
\hline \multirow[t]{2}{*}{ Acropora sp. 1} & 1 & 24 Feb ‘05 & 2 Mar ‘05 & 6 \\
\hline & 9 & 2 Mar ‘05 & 3 Mar ‘05 & 1 \\
\hline \multicolumn{5}{|l|}{ 4th quarter } \\
\hline \multirow[t]{2}{*}{ A. humilis } & 3 & 31 Jan ‘05 & 3 Feb ‘05 & 3 \\
\hline & 1 & 3 Feb ‘05 & 6 Feb ‘05 & 3 \\
\hline A. kosurini & 1 & 31 Jan ‘05 & 6 Feb ‘05 & 6 \\
\hline \multirow[t]{3}{*}{ A. mossambica } & 3 & 31 Jan ‘05 & 3 Feb ‘05 & 3 \\
\hline & 2 & 31 Jan ’05 & 6 Feb ‘05 & 6 \\
\hline & 4 & 2 Mar ‘05 & 5 Mar ‘05 & 3 \\
\hline A. sordiensis & 1 & 31 Jan ‘05 & 6 Feb ‘05 & 6 \\
\hline \multirow[t]{2}{*}{ A. tenuis } & 1 & 3 Feb ‘05 & 6 Feb ‘05 & 3 \\
\hline & 1 & 2 Mar `05 & 5 Mar ‘05 & 3 \\
\hline A. valida & 2 & 31 Jan ‘05 & 3 Feb ‘05 & 3 \\
\hline Acropora sp. 1 & 3 & 31 Jan ‘05 & 3 Feb ‘05 & 3 \\
\hline Total colonies & 78 & & & \\
\hline
\end{tabular}

tion (Oliver et al. 1988). The present study found that coral reproduction occurred predominantly during the northeast monsoon, from December to March, when prevailing wind and sea conditions are calm and rainfall is low, which suggests that there may be a correlation between monsoon seasons and reproduction in Kenya. While the exact night of spawning was recorded in 2 Acropora species, the narrowing of spawning times to lunar months and lunar quarters, and the overlap between reproducing species during these periods suggests that some degree of multi- specific spawning is a characteristic of Kenyan reefs. In addition, reproductive data published on Platygyra daedalea and Echinopora gemmacea (Mangubhai \& Harrison 2006, 2008), and the presence of pigmented oocytes in colonies of Leptoria phrygia, Hydnophora exesa, Turbinaria mesenterina, Favites pentagona and Astreopora listeri sampled in December 2004 (Mangubhai 2007), provides further evidence that other coral species, genera and families are reproductively mature during the summer months of the northeast monsoon in Kenya.

The extended seasonal pattern of spawning recorded in Kenya supports the statement by Guest et al. (2005b) that no coastal environment is truly aseasonal and, therefore, reproductive seasonality and some degree of multispecific spawning may occur on equatorial reefs. However, the suggestion that mass spawning is a characteristic of equatorial reefs (Guest et al. 2005b) is not supported by the coral reproductive data from this study or from Oliver et al. (1988). In contrast to many tropical reefs, reproductive patterns in broadcast spawning corals are highly asynchronous in Kenya. Spawning among Acropora and faviids occurs over 9 mo, from August to April (Mangubhai \& Harrison 2006, 2008, Mangubhai 2007), with the various coral species displaying some degree of temporal reproductive isolation (sensu Shlesinger \& Loya 1985) in relation to the main lunar month and lunar quarter when spawning occurs. In the northern Red Sea and Caribbean, where corals studied display a higher level of asynchrony, spawning occurs over 6 mo (Shlesinger \& Loya 1985, Shlesinger et al. 1998) and 4 mo (Szmant 1986, Van Veghel 1994), respectively. Therefore, Kenyan coral reefs have the longest reproductive season recorded thus far for broadcast spawning corals. Furthermore, the findings of this study support the hypotheses that reproductive seasons may be more protracted towards lower latitudes (Orton 1920, Pearse 1974) and that mass spawning does not occur in equatorial regions due to a breakdown in spawning synchrony (Oliver et al. 1988).

Although reproduction occurs during 9 mo of the year, there was no evidence from the present study to suggest that broadcast-spawning corals were capable of reproducing year-round, as suggested for other invertebrate groups (Orton 1920, Pearse 1974). The lack of year-round spawning in Acropora and faviid species (Mangubhai \& Harrison 2006, 2008, Mangubhai 2007) is likely to reflect life-history patterns, energetic and physiological constraints within this sexual pattern and mode of reproduction or within the species studied. Year-round spawning is more likely to occur in brooding species than broadcast spawners in equatorial regions (Atoda 1947a,b, Kojis 1986), because brooders have a greater propensity for multiple cycles of gameto- 

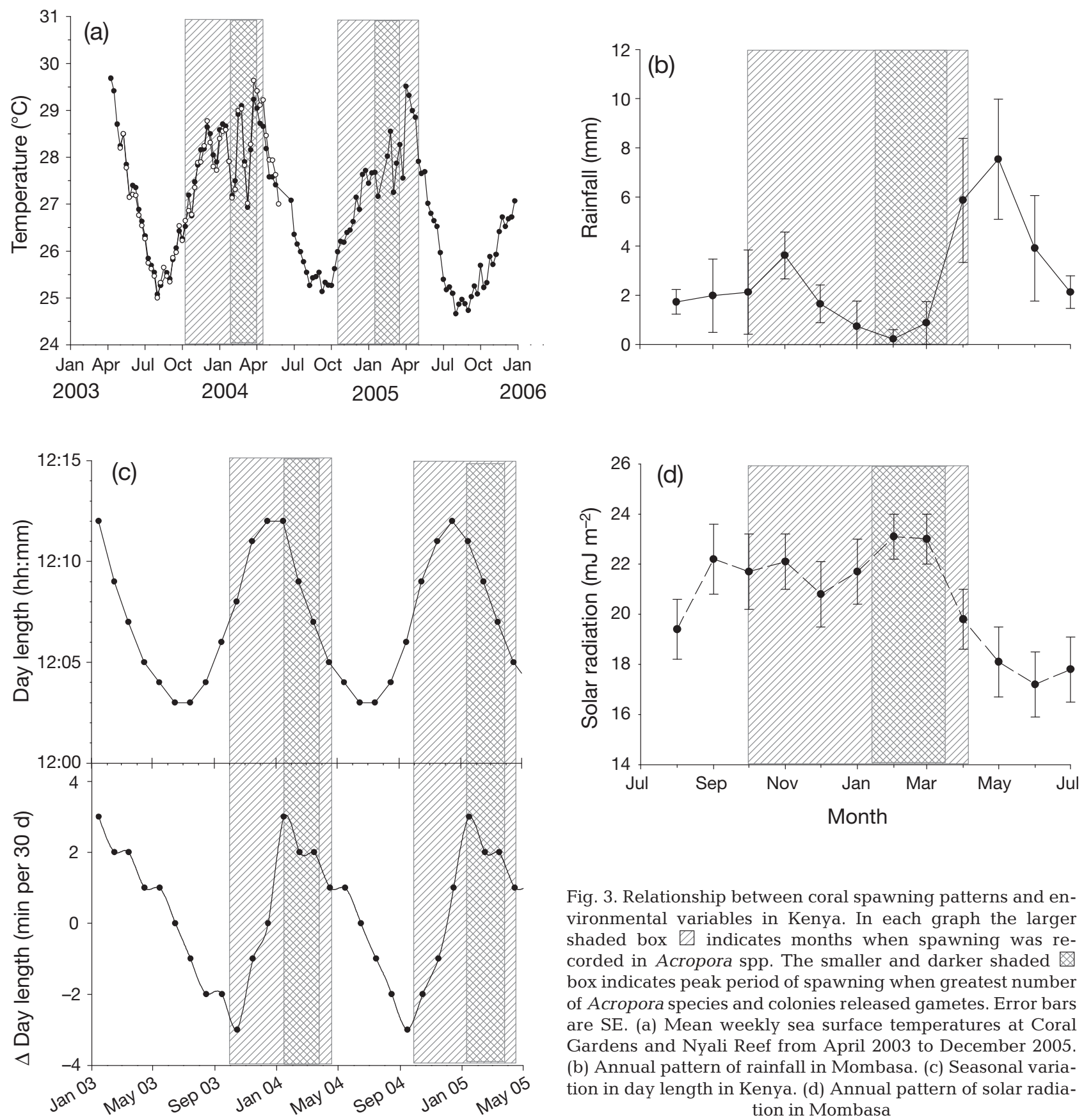

Fig. 3. Relationship between coral spawning patterns and environmental variables in Kenya. In each graph the larger shaded box $\square$ indicates months when spawning was recorded in Acropora spp. The smaller and darker shaded $x$ box indicates peak period of spawning when greatest number of Acropora species and colonies released gametes. Error bars are SE. (a) Mean weekly sea surface temperatures at Coral Gardens and Nyali Reef from April 2003 to December 2005. (b) Annual pattern of rainfall in Mombasa. (c) Seasonal variation in day length in Kenya. (d) Annual pattern of solar radiation in Mombasa

genesis (reviewed by Harrison \& Wallace 1990). Settlement patterns of pocilloporids and poritids in Kenya suggest that year-round sexual reproduction may occur in these 2 taxonomic groups, as evidenced by the presence of settled spat on artificial settlement tiles in all 3 mo immersion periods of the year (Mangubhai et al. 2007a). However, biannual cycles of gametogenesis occurred in 1 colony each of A. valida and Acropora sp. 1 and in some colonies of Platygyra daedalea (Mangubhai \& Harrison 2008), and 2 overlapping oogenic cycles were recorded in Leptoria phrygia (Mangubhai
2007) in Kenya, and in some broadcast-spawning corals on equatorial reefs in PNG (Oliver et al. 1988) and Singapore (Guest et al. 2005b). Therefore, biannual cycles of gametogenesis can occur in some broadcastspawning species in equatorial regions.

In addition to the present study, only one other medium-term, multi-species reproductive study has been undertaken to describe reproductive patterns in scleractinian corals on equatorial reefs. However, it is difficult to compare the asynchronous spawning patterns recorded in Kenya with patterns recorded in 
Singapore (Guest et al. 2005a,b) because different methods were used and the data are not directly comparable. The sampling strategy used in Kenya allowed patterns of gametogenesis and spawning to be interpreted at both the individual and population level, which is important for quantifying reproduction in populations with extended breeding periods. While the majority of spawning occurred from March to April in Singapore, the presence of gametes in Acropora species over 10 mo of the year and the presence of gametes in October/November in Platygyra sp. and Porites lutea (Guest et al. 2005b) suggest that corals in Singapore may also spawn over an extended period. There is also some evidence to suggest that protracted breeding seasons occur on equatorial reefs in Palau, with broadcast spawning occurring from April to September and in February (Kenyon 1995, Penland et al. 2004) and that year-round planulation occurs in a number of pocilloporid species (Atoda 1947a,b). Other studies on equatorial reefs are either short (e.g. Kenyon 1995, Baird et al. 2002) and/or involve single or too few species (e.g. Kojis 1986, Mangubhai et al. 2007b), and therefore do not provide extensive information on reproductive patterns on low-latitude reefs with asynchronous spawning and protracted breeding seasons.

In Kenya, protracted breeding seasons are not limited to scleractinian corals; they also occur in other reef invertebrates and fish, with most species showing distinct seasonal patterns (Nzioka 1979, Kulmiye et al. 2002, Muthiga 2003, 2006 Muthiga \& Jaccarini 2005). For example, the sea urchin Echinometra mathaei spawns over 6 mo in Kenya, with peak spawning from February to May (Muthiga \& Jaccarini 2005), while Holothuria arenacava spawns over 3 mo, from March to May (Muthiga 2006). The emperor fish Lethrinus harak has a prolonged spawning season in Kenya, from October to April, with spawning peaks in the inter-monsoonal months of October and April (Kulmiye et al. 2002), and 6 Lutjanus species (snappers) spawn over a period of 2 to 6 mo, with spawning peaking in October (Nzioka 1979). Furthermore, barnacles, bryozoans, serpulids and oysters settle on artificial substrata throughout the year, with peak settlement in the different groups occurring in different 3 mo periods of the year (Mangubhai et al. 2007a).

Other studies from equatorial regions outside of East Africa also support the hypotheses of protracted breeding seasons and a breakdown in spawning synchrony at the equator. Srinivasan \& Jones (2006) found that in 40 of the most abundant fish species (6 families) in Kimbe Bay, PNG $\left(5^{\circ} \mathrm{S}\right)$, recruitment occurred over 6 to 12 mo, with most wrasse species exhibiting year-round recruitment and seasonal peaks in recruitment. The sea urchin Diadema setosum has continuous reproduction on equatorial reefs in Singapore (Hori et al. 1987) and Kenya (Muthiga 2003), but spawns only in the summer months in tropical and higher latitude reefs in the Gulf of Suez, northern Red Sea, Japan and on the GBR (Pearse 1974). Extended aseasonal patterns of reproduction were recorded for the barnacle Chthamalus malayensis in Singapore and Malaysia $\left(2^{\circ} \mathrm{N}\right)$ (Koh et al. 2005), and Marcia species in Singapore (Tan 1994 cited in Koh et al. 2005). Therefore, there is a growing body of evidence that indicates that there is a reduction in the degree of spawning synchrony on equatorial reefs, with breeding seasons becoming more protracted temporally and that these patterns extend to a range of marine organisms, and include at least some scleractinian corals.

\section{Proximate cues and ultimate factors}

The discovery of asynchronous spawning and protracted breeding seasons in coral species on equatorial reefs in Kenya poses important theoretical questions about the evolutionary and ecological advantages ('ultimate factors') of asynchronous spawning and the role of different environmental variables ('proximate cues') in determining spawning patterns at different latitudes. The confounding effects of different nonindependent environmental variables makes it difficult to assess the role(s) individual variables have on reproductive processes in marine organisms, and the degree and extent to which they operate in synergy, or otherwise (reviewed in Harrison \& Wallace 1990).

Annual SST and tidal ranges are not uniform and can vary between different equatorial regions. In Kenya, Echinopora gemmacea, Leptoria phrygia, the majority of Platygyra daedalea (Mangubhai \& Harrison 2006, 2008, Mangubhai 2007) and many Acropora species spawned when mean SSTs were at their annual summer maximum during the northeast monsoon season. However, $42 \%$ of Acropora species also spawned during rising SSTs, which suggests that for some coral groups, such as Acropora, there may be factors other than temperature that influence the timing of spawning, or alternatively, that there is a wider range in optimal or ecologically appropriate temperatures for spawning in this genus. More recently it has been suggested that the rate of change and cumulative response of solar insolation cycles is a better predictor of coral reproduction than SST or solar intensity at the time of spawning (Penland et al. 2004, van Woesik et al. 2006). This hypothesis is also based on correlative evidence and requires further testing across a wider range of geographic locations and controlled experiments to differentiate the influence of sea temperature from solar insolation cycles. However, coral spawning data from Kenya does not support this hypothesis, as 
Kenyan corals spawn over a 9 mo period.

The 3 faviids studied in Kenya spawned mainly on spring tides (Mangubhai 2007, Mangubhai \& Harrison 2008), while Acropora species spawned over a range of tides from springs to neaps, which suggests that tidal phase may not play a strong role in determining the timing of spawning in corals in Kenya. Although there was a greater tendency for faviid (Mangubhai 2007, Mangubhai \& Harrison 2008) and Acropora species to spawn in the third lunar quarter, spawning was recorded in all lunar phases, mainly as a result of the asynchronous pattern recorded in Acropora species. Therefore, lunar cycles do not appear to fine-tune coral spawning in Kenya to the same degree and extent recorded in other locations (Harrison \& Wallace 1990).

One environmental cue that has been largely overlooked or ignored is the role of photoperiod in controlling reproduction and synchronising spawning in corals (Harrison \& Wallace 1990). Photoperiod cycles are more consistent because of their independence from seasonal and inter-annual variation in climate and, therefore, may provide a more reliable cue in synchronising gametogenic cycles in marine organisms. In equatorial regions, day length remains fairly consistent, with changes of $\leq 30 \mathrm{~min} \mathrm{yr}^{-1}$, compared to other environmental variables, such as temperature and tidal amplitude, which may vary between locations. Therefore, it is equally plausible to argue that under conditions of more consistent day length, spawning synchrony may break down and extended breeding seasons may occur. This hypothesis does not imply that sensitivity to changes in photoperiod are lost in equatorial regions, nor does it exclude the role other variables, such as temperature or solar radiation, may have in fine-tuning reproductive cycles and the timing of spawning. For example, Kenyan corals spawn generally during periods when light intensity is above $20 \mathrm{MJ} \mathrm{m}^{-2}$, which suggests that light energy may also play an indirect role in the timing of spawning events.

The ultimate factors influencing spawning patterns are still poorly understood and remain largely theoretical (reviewed by Harrison \& Wallace 1990, Harrison \& Booth 2007). Splitspawning at the population level may be a strategy to reduce the impact of a single catastrophic event on a population's entire reproductive outputs for any given year (Harrison et al. 1984). Alternatively, it may provide an opportunity for colonies that were not fully reproductive, or were stressed to participate in a spawning event (Shimoike et al. 1992, Van Veghel 1994), or for reducing interspecific competition among corals during settlement (Shlesinger \& Loya 1985, Mangubhai et al. 2007a). However, there may be disadvantages to split-spawning, such as gamete wastage, non-viable hybridisation, and low rates of fertilisation and outcrossing in self-fertile hermaphrodites (reviewed in Harrison \& Wallace 1990). Oliver \& Babcock (1992) found fertilisation success was dependent on the proportion of the colonies spawning, with lower fertilisation rates recorded in coral spawning slicks on the GBR on minor spawning nights than on major spawning nights. Babcock \& Mundy (1992) found similar results when comparing fertilisation rates in crown-of-thorns starfish during minor and major spawning events. Experimental manipulations have also shown that there are optimum sperm concentrations for achieving high fertilisation rates, and this is

Table 4. Acropora spp. Comparisons of mean oocyte size and fecundity (oocytes polyp $\mathrm{p}^{-1}$ ) recorded at different geographic locations for which data are available for Kenya (bold). For each species, data are ordered in decreasing mean oocyte size. Oocyte sizes measured by tissue dissection under a stereomicroscope. (-) no data available. GBR: Great Barrier Reef

\begin{tabular}{|c|c|c|c|c|}
\hline Species & Location & $\begin{array}{c}\text { Oocyte } \\
\text { size }(\mu \mathrm{m})\end{array}$ & Fecundity & Source \\
\hline \multirow[t]{3}{*}{ A. cytherea } & Kenya & 558 & 6.9 & Present study \\
\hline & Taiwan & 486 & - & Dai et al. (1992) \\
\hline & W. Australia & 440 & 10.0 & Rosser (2005) \\
\hline \multirow[t]{3}{*}{ A. digitifera } & W. Australia & 585 & 11.6 & Rosser (2005) \\
\hline & Kenya & 475 & 8.7 & Present study \\
\hline & Japan & - & 7.8 & Shimoike et al. (1992) \\
\hline \multirow[t]{2}{*}{ A. divaricata } & Taiwan & 622 & - & Dai et al. (1992) \\
\hline & Kenya & 407 & 18.9 & Present study \\
\hline \multirow[t]{2}{*}{ A. glauca } & Solitary Is. (Aus) & 703 & 10.6 & Wilson (1998) \\
\hline & Kenya & 417 & 14.4 & Present study \\
\hline \multirow{3}{*}{ A. humilis } & Hawaii & 714 & 7.3 & Kenyon (1992) \\
\hline & Taiwan & 507 & - & Dai et al. (1992) \\
\hline & Kenya & 451 & 19.7 & Present study \\
\hline \multirow[t]{2}{*}{ A. lutkeni } & Solitary Is. (Aus) & 627 & 9.9 & Wilson (1998) \\
\hline & Kenya & 492 & 19.2 & Present study \\
\hline \multirow[t]{2}{*}{ A. nana } & Taiwan & 568 & - & Dai et al. (1992) \\
\hline & Kenya & 493 & 10.6 & Present study \\
\hline \multirow[t]{3}{*}{ A. nasuta } & Taiwan & 646 & - & Dai et al. (1992) \\
\hline & Kenya & 523 & 11.0 & Present study \\
\hline & Japan & - & 9.4 & Shimoike et al. (1992) \\
\hline \multirow[t]{2}{*}{ A. samoensis } & W. Australia & 520 & 10.7 & Rosser (2005) \\
\hline & Kenya & 434 & 16.0 & Present study \\
\hline \multirow[t]{2}{*}{ A. secale } & Palau & 674 & - & Kenyon (1995) \\
\hline & Kenya & 499 & 15.1 & Present study \\
\hline \multirow[t]{2}{*}{ A. tenuis } & W. Australia & 605 & 10.5 & Rosser (2005) \\
\hline & Kenya & 448 & 17.9 & Present study \\
\hline \multirow[t]{5}{*}{ A. valida } & Solitary Is. (Aus) & 697 & 10.0 & Wilson (1998) \\
\hline & Hawaii & 644 & 7.3 & Kenyon (1992) \\
\hline & GBR & 633 & 5.6 & Wallace (1985) \\
\hline & Kenya & 468 & 16.7 & Present study \\
\hline & Taiwan & 390 & - & Dai et al. (1992) \\
\hline
\end{tabular}


thought to be maximised by species synchronising their spawning periods (Babcock \& Mundy 1992, Oliver \& Babcock 1992).

The findings of these GBR studies suggest that an asynchronous pattern of spawning in scleractinian corals is likely to result in lower rates of fertilisation and hence would potentially reduce recruitment and the rate of propagation of a species. However, this may not be the case in Kenya or on equatorial reefs in general, given that high biological diversity and flourishing reefs are found at low latitudes (Wallace 1999, Veron 2000). Coral fecundity in both faviid (Mangubhai 2007, Mangubhai \& Harrison 2008) and Acropora (Table 4), species was higher in Kenya than in other regions, and we propose that these high fecundities may allow corals to stagger their reproduction over 2 to 5 mo without incurring a significant reduction in fertilisation rates. This argument is supported by models of egg size and sperm limitation proposed by Levitan (1993). Models of optimum egg size indicate that smaller egg sizes and greater sperm motility are selected for when sperm availability is higher (Levitan $\&$ Petersen 1995). The reduction in fertilisation associated with smaller egg sizes is compensated for by a higher fecundity, which increases the probability of zygote production (Levitan 1993, Podolsky \& Strathmann 1996). In Kenya there was a significant positive relationship between number of eggs (polyp fecundity) and mean spermary sizes in Acropora species; therefore, there may be a relationship between sperm concentration and fecundity that maximises zygote production. In addition, the presence of sperm-attractant molecules in the eggs of some coral species (Coll et al. 1994) would increase the effective surface area of eggs, without increasing the amount of energy invested per egg.

With so few detailed studies on reproduction in scleractinian corals in equatorial regions, it is not possible to determine whether the reproductive patterns recorded in this study are unique to Kenya or reflect a general latitudinal trend that applies to corals on many other equatorial reefs. However, there is growing supporting evidence from other marine invertebrate groups, such as sea urchins, holothurians and barnacles, as well as fish, to suggest that protracted breeding seasons and spawning asynchrony are features of many equatorial reefs. It is clear that there is no simple relationship between latitude or the range and amplitude of environmental variables that determines the degree of synchrony exhibited by corals. Further detailed medium- to long-term studies in equatorial regions across a wider range of longitudes will elucidate the extent to which spawning synchrony breaks down at lower latitudes and the roles of different environmental variables on equatorial reefs.
Acknowledgements. This research was supported by CORDIO East Africa and the Kenya Wildlife Service. H. Pargeter assisted in the field and laboratory. Our sincere thanks go to C. Wallace, Museum of Tropical Queensland, for her guidance with identifying Acropora species. We are grateful for the comments of our reviewers that helped to improve this manuscript. This work was done under a Kenyan research permit (MOEST 13/001/32C-15) and made possible by a Southern Cross University grant to S.M.

\section{LITERATURE CITED}

Alino PM, Coll JC (1989) Observations of the synchronized mass spawning and postsettlement activity of octocorals on the Great Barrier Reef, Australia: biological aspects. Bull Mar Sci 45:697-707

Atoda K (1947a) The larva and postlarval development of some reef-building corals. I. Pocillopora damicornis cespitosa (Dana). Sci Rep Tohoku Univ Ser 7 4:24-47

Atoda K (1947b) The larva and postlarval development of some reef-building corals. II. Stylophora pistillata (Esper). Sci Rep Tohoku Univ Ser 7 4:48-64

Babcock RC, Mundy CN (1992) Reproductive biology, spawning and field fertilization rates of Acanthaster planci. Aust J Mar Freshw Res 43:525-534

Babcock RC, Bull GD, Harrison PL, Heyward AJ, Oliver JK, Wallace CC, Willis BL (1986) Synchronous spawnings of 105 scleractinian coral species on the Great Barrier Reef. Mar Biol 90:379-394

Babcock R, Mundy C, Keesing J, Oliver J (1992) Predictable and unpredictable spawning events: in situ behavioural data from free-spawning coral reef invertebrates. Invertebr Reprod Dev 22:213-228

Babcock RC, Willis BL, Simpson CJ (1994) Mass spawning of corals on a high latitude coral reef. Coral Reefs 13:161-169

Baird AH, Marshall PA, Wolstenholme J (2002) Latitudinal variation in the reproduction of Acropora in the Coral Sea. Proc 9th Int Coral Reef Symp 1:385-389

Coll JC, Bowden BF, Meehan GV, Konig GM and others (1994) Chemical aspects of mass spawning in corals. I. Sperm-attractant molecules in the eggs of the scleractinian coral Montipora digitata. Mar Biol 118:177-182

Dai CF, Soong K, Fan TY (1992) Sexual reproduction of corals in northern and southern Taiwan. Proc 7th Int Coral Reef Symp 1:448-455

Guest JR, Baird AH, Goh BPL, Chou LM (2005a) Reproductive seasonality in an equatorial assemblage of scleractinian corals. Coral Reefs 24:112-116

Guest JR, Baird AH, Goh BPL, Chou LM (2005b) Seasonal reproduction in equatorial reef corals. Invertebr Reprod Dev 48:207-218

Harrison PL, Booth DJ (2007) Coral reefs: naturally dynamic and increasingly disturbed ecosystems. In: Connell SD, Gillanders BM (eds) Marine ecology. Oxford University Press, Oxford, p 316-377

Harrison PL, Wallace CC (1990) Reproduction, dispersal and recruitment of scleractinian corals. In: Dubinsky Z (ed) Ecosystems of the world: coral reefs, Vol 25. Elsevier, Amsterdam, p 133-207

> Harrison PL, Babcock RC, Bull GD, Oliver JK, Wallace CC, Willis BL (1984) Mass spawning in tropical reef corals. Science 223:1186-1189

> Hayashibara T, Shimoike K, Kimura T, Hosaka S and others (1993) Patterns of coral spawning at Akajima Island, Okinawa, Japan. Mar Ecol Prog Ser 101:253-262

Hori R, Phang VPE, Lam TJ (1987) Preliminary study on the 
pattern of gonadal development of the sea urchin, Diadema setosum, off the coast of Singapore. Zoolog Sci 4:665-673

Kenyon JC (1992) Sexual reproduction in Hawaiian Acropora. Coral Reefs 11:37-43

Kenyon JC (1995) Latitudinal differences between Palau and Yap in coral reproductive synchrony. Pac Sci 49:156-164

Koh LL, O'Riordan RM, Lee WJ (2005) Sex in the tropics: reproduction of Chthamalus malayensis Pilsbury (Class Cirripedia) at the equator. Mar Biol 147:121-133

Kojis BL (1986) Sexual reproduction in Acropora (Isopora) (Coelenterata: Scleractinia) II. Latitudinal variation in $A$. palifera from the Great Barrier Reef and Papua New Guinea. Mar Biol 91:311-318

Kulmiye AJ, Ntiba MJ, Kisia SM (2002) Some aspects of the reproductive biology of the thumbprint emperor, Lethrinus harak (Forsskål, 1775), in Kenyan coastal waters. Western Indian Ocean J Mar Sci 1:135-144

Lessios HA (1981) Reproductive periodicity of the echinoids Diadema and Echinometra on the two coasts of Panama. J Exp Mar Biol Ecol 50:47-61

Levitan DR (1993) The importance of sperm limitation to the evolution of egg size in marine invertebrates. Am Nat 141: $517-536$

Levitan DR, Petersen C (1995) Sperm limitation in the sea. Trends Ecol Evol 10:228-231

Mangubhai S (2007) Reproduction and recruitment of scleractinian corals on equatorial reefs in Mombasa, Kenya. PhD thesis, Southern Cross University, Lismore, NSW

Mangubhai S, Harrison PL (2006) Seasonal patterns of coral reproduction on equatorial reefs in Mombasa, Kenya. Proc 10th Int Coral Reef Symp p 106-114

Mangubhai S, Harrison PL (2008) Gametogenesis, spawning and fecundity of Platygyra daedalea (Scleractinia) on equatorial reefs in Kenya. Coral Reefs. 27:117-122

Mangubhai S, Harrison PL, Obura DO (2007a) Patterns of coral larval settlement on lagoonal reefs in the Mombasa Marine National Park and Reserve in Kenya. Mar Ecol Prog Ser 348:149-159

> Mangubhai S, Harris A, Graham NJA (2007b) Synchronous daytime spawning of the solitary coral Fungia danai (Fungiidae) in the Chagos Archipelago, central Indian Ocean. Coral Reefs 26:15

Muthiga NA (2003) Coexistence and reproductive isolation of the sympatric echinoids Diadema savignyi Michelin and Diadema setosum (Leske) on Kenya coral reefs. Mar Biol 143:669-677

Muthiga NA (2006) The reproductive biology of a new species of sea cucumber, Holothuria (Mertensiothuria) arenacava in a Kenyan marine protected area: the possible role of light and temperature on gametogenesis and spawning. Mar Biol 149:585-593

Muthiga NA, Jaccarini V (2005) Effects of seasonality and population density on the reproduction of the Indo-Pacific echinoid Echinometra mathaei in Kenyan coral reef lagoons. Mar Biol 146:445-453

Nzioka RM (1979) Observations on the spawning seasons of East African reef fishes. J Fish Biol 14:329-342

Oliver J, Babcock R (1992) Aspects of the fertilization ecology of broadcast spawning corals: sperm dilution effects and in situ measurements of fertilization. Biol Bull 183:409-417

Oliver JK, Babcock RC, Harrison PL, Willis BL (1988) Geographic extent of mass coral spawning: clues to ultimate causal factors. Proc 6th Int Coral Reef Symp 2: $803-810$
Orton JH (1920) Sea-temperature, breeding and distribution in marine animals. J Mar Biol Assoc UK 12:339-366

Pearse JS (1969) Reproductive periodicities of Indo-Pacific invertebrates in the Gulf of Suez. II. The echinoid Echinometra mathaei (De Blainville). Bull Mar Sci 19:580-613

Pearse JS (1974) Reproductive patterns of tropical reef animals: three species of sea urchins. Proc 2nd Int Coral Reef Symp 1:235-240

Pearse JS, McClary DJ, Sewell MA, Austin WC, Perez-Ruzafa A, Byrne M (1988) Simultaneous spawning of six species of echinoderms in Barkley Sound, British Columbia. Invertebr Reprod Dev 14:279-288

> Penland L, Kloulechad J, Idip D, van Woesik R (2004) Coral spawning in the western Pacific Ocean is related to solar insolation: evidence of multiple spawning events in Palau. Coral Reefs 23:133-140

Podolsky RD, Strathmann RR (1996) Evolution of egg size in free-spawners: consequences of the fertilization-fecundity trade-off. Am Nat 148:160-173

Rosser NL (2005) Reproductive seasonality and biannual spawning of Acropora on two northwest Australian reefs. Honours thesis, Murdoch University, Perth, WA

Shimoike K, Hayashibara T, Kimura T, Omori M (1992) Observations of split spawning in Acropora spp. at Akajima Island, Okinawa. Proc 7th Int Coral Reef Symp 1: $484-488$

Shlesinger Y, Loya Y (1985) Coral community reproductive patterns: Red Sea versus the Great Barrier Reef. Science 228:1333-1335

- Shlesinger Y, Goulet TL, Loya Y (1998) Reproductive patterns of scleractinian corals in the northern Red Sea. Mar Biol 132:691-701

Simpson CJ (1991) Mass spawning of corals on Western Australian reefs and comparisons with the Great Barrier Reef. J R Soc West Aust 74:85-91

Srinivasan M, Jones GP (2006) Extended breeding and recruitment periods of fishes on a low latitude coral reef. Coral Reefs 25:673-682

Szmant AM (1986) Reproductive ecology of Caribbean reef corals. Coral Reefs 5:43-53

Tan HK (1994) Seasonal reproductive activity in bivalves of the genus Marcia. PhD thesis, National University of Singapore, Singapore

Van Veghel MLJ (1994) Reproductive characteristics of the polymorphic Caribbean reef building coral Montastrea annularis. I. Gametogenesis and spawning behavior. Mar Ecol Prog Ser 109:221-227

van Woesik R, Lacharmoise F, Köksal S (2006) Annual cycles of solar insolation predict spawning times of Caribbean corals. Ecol Lett 9:390-398

Veron JEN (2000) Corals of the world. Australian Institute of Marine Science, Townsville

Wallace CC (1985) Reproduction, recruitment and fragmentation in nine sympatric species of the coral genus Acropora. Mar Biol 88:217-233

Wallace CC (1999) Staghorn corals of the world: a revision of the coral genus Acropora. CSIRO, Collingwood

Willis BL, Babcock RC, Harrison PL, Oliver JK, Wallace CC (1985) Patterns in the mass spawning of corals on the Great Barrier Reef from 1981 to 1984. Proc 5th Int Coral Reef Cong 4:343-348

Wilson JR (1998) Reproduction and larval ecology of broadcast spawning corals at the Solitary Islands, Eastern Australia. PhD thesis, Southern Cross University, Lismore, NSW 